\title{
Technical Note: A Simple Salting-Out Method for DNA Extraction from Milk Somatic Cells: Investigation into the Goat CSN1S1 Gene
}

\author{
F. d'Angelo, ${ }^{*}$ A. Santillo, ${ }^{*}$ A. Sevi, ${ }^{*} \dagger$ and M. Albenzio* ${ }^{1}$ \\ *Dipartimento PRIME, and \\ †Istituto per la Ricerca e le Applicazioni Biotecnologiche per la Sicurezza e la Valorizzazione dei Prodotti Tipici e di Qualità (BIOAGROMED), \\ Università di Foggia, Via Napoli 25, 71100 Foggia, Italy
}

\section{ABSTRACT}

In this study, a sensitive, rapid, and toxic solventfree method to extract DNA from milk somatic cells was implemented for characterization of the goat $\alpha_{\mathrm{S}^{-}}$ casein gene (CSN1S1). Methods reported for purification of DNA from milk often involve organic extraction, overnight incubation, or use of expensive commercial kits. The present method was implemented for goat milk and is based on a salting-out protocol. The method yielded an amount of DNA suitable for PCR-RFLP without the need for sample enrichment. The PCRRFLP of DNA extracted from milk produced amplified and digested products of correct size, comparable with those obtained using PCR-RFLP of DNA extracted from blood. Therefore, milk can be used as an alternative source of DNA, making sample collection easier and reducing stressful practices such as capture, handling, and venipuncture in animal management.

Key words: milk somatic cell, DNA extraction, salting-out, polymerase chain reaction-restriction fragment length polymorphism

In recent years, genetic techniques have come to be a powerful tool in several livestock applications. The DNA-based methods such as PCR are increasingly used in population genetic variability studies, QTL identification, marker-assisted selection, and food traceability. These techniques require extraction methods that guarantee effective recovery of nucleic acid and removal of PCR inhibitors. Blood leukocytes are generally used as a source of DNA. Nevertheless, collection of blood samples causes technical difficulties and leads to stress for animals. Several studies have developed methods to extract DNA directly from milk somatic cells instead of blood and use organic extraction, overnight incubation, or expensive commercial kits (Lipkin et al., 1993; Amills et al., 1997; Feligini

Received February 27, 2007.

Accepted April 5, 2007.

${ }^{1}$ Corresponding author: m.albenzio@unifg.it et al., 2005; Cremonesi et al., 2006). Because milk secretion in the goat is apocrine, somatic cells in goat milk consist of leukocytes, epithelial cells, and cytoplasmic particles that are mostly anucleated. White blood cells are represented by macrophages, lymphocytes, and polymorphonuclear leukocytes (Paape et al., 2007). Milk is preferred to blood as a source of DNA because milk collection is routinely performed and is less expensive and more easily accomplished than blood collection. It is also less stressful to animals, given that capture, handling, and venipuncture are not required for milk sampling.

In this article, a reliable method for sensitive, rapid, and toxic solvent-free DNA extraction directly from goat raw milk is described. This method was implemented for identification of the CSN1S1 alleles using PCR-RFLP. The importance of goat CSN1S1 polymorphism is due to its qualitative and quantitative implications. Protein level and composition could be involved in the use of goats' milk as an alternative milk source in patients with cows' milk allergy, or to benefit from the technological properties of goat milk.

Milk and blood samples were collected from 40 Garganica goats for genomic DNA extraction. Milk samples were analyzed for fat $(5.96 \pm 1.24 \%)$, protein $(4.46$ $\pm 0.66 \%$ ) , and lactose $(4.22 \pm 0.27 \%)$ content (MilkoScan 133B, Foss Electric, Hillerød, Denmark). Somatic cell count $(1,350,000 \pm 129,000$ cells $/ \mathrm{mL})$ was determined using a Fossomatic 90 (Foss Electric) according to the International Dairy Federation standard (IDF, 1995).

Genomic DNA was extracted from milk according to the procedure described for blood (d'Angelo et al., 2006), with some modifications. Forty milliliters of raw milk was centrifuged at $4^{\circ} \mathrm{C}$ for $30 \mathrm{~min}$ at $2,000 \times g$. The fat layer and the supernatant were discarded. The

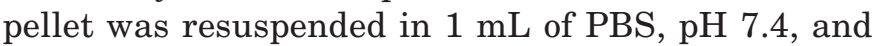
centrifuged at $4^{\circ} \mathrm{C}$ for $10 \mathrm{~min}$ at $400 \times \mathrm{g}$. The pellet was then resuspended in $49 \mathrm{~mL}$ of lysis buffer $(0.32$ $M$ sucrose, $10 \mathrm{~m} M$ Tris- $\mathrm{HCl}, \mathrm{pH} 7.5,5 \mathrm{mM} \mathrm{MgCl} 2$, and $1 \%$ Triton X-100). The nuclei pellet was centrifuged at $2,465 \times \mathrm{g}$ for $10 \mathrm{~min}$ at $4^{\circ} \mathrm{C}$ and washed twice with 


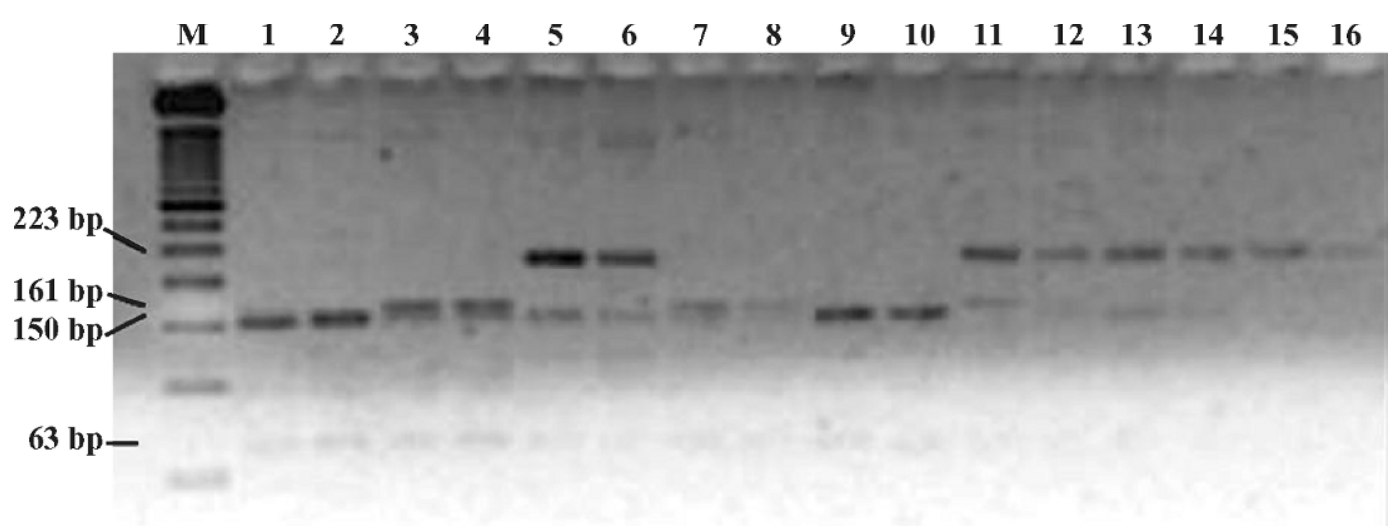

Figure 1. Agarose gel electrophoresis of PCR products digested with XmnI. M = marker, 50-bp DNA ladder; lanes 1, 3, 5, 7, 9, 11, 13, and 15 = blood samples; lanes $2,4,6,8,10,12,14$, and $16=$ milk samples. Haplotypes: 223 bp in the presence of both mutations (associated with CSN1S1 ${ }^{\mathrm{F}}$ allele); $63 \mathrm{bp}+161 \mathrm{bp}$ in the presence of the 11-bp insertion (associated with CSN1S1 ${ }^{\mathrm{B}}$ and CSN1S1 $1^{\mathrm{E}}$ alleles); $63 \mathrm{bp}+150$ $\mathrm{bp}$ in the absence of both the mutations (associated with CSN1S1 ${ }^{\mathrm{A}}, \mathrm{CSN}_{1} 1^{10}$, and CSN1S1 ${ }^{\mathrm{N}}$ alleles).

$10 \mathrm{~mL}$ of $0.075 \mathrm{M} \mathrm{NaCl}, 0.025 M$ EDTA. The pellet was then resuspended in $3 \mathrm{~mL}$ of $10 \mathrm{~m} M$ Tris-HCl, $\mathrm{pH}$ 8.0, and $2 \mathrm{~m} M$ EDTA; then, $100 \mu \mathrm{L}$ of $10 \%$ SDS and $40 \mu \mathrm{L}$ of proteinase $\mathrm{K}(10 \mathrm{mg} / \mathrm{mL})$ were added. The resulting nuclear lysate was incubated at $65^{\circ} \mathrm{C}$ for 1 h. After incubation, $500 \mu \mathrm{L}$ of $5 \mathrm{M} \mathrm{NaCl}$ was added and the precipitated proteins were centrifuged at $1,811 \times$ $g$ for $10 \mathrm{~min}$. The aqueous layer was recovered and DNA precipitated after addition of $6 \mathrm{~mL}$ of isopropanol and centrifugation for $10 \mathrm{~min}$ at $1,811 \times \mathrm{g}$. The resulting pellet was dried at room temperature and then redissolved in $500 \mu \mathrm{L}$ of Tris-EDTA (10 $\mathrm{mM}$ Tris, 1 $\mathrm{m} M$ EDTA, $\mathrm{pH}$ 7.5).

Total DNA yield ranged from 65 to $245 \mu \mathrm{g}$ per blood sample, and from 2.12 to $610.12 \mu \mathrm{g}$ per milk sample. Somatic cell counts for these samples ranged from 79 $\times 10^{3}$ to $40 \times 10^{5}$ cells per $\mathrm{mL}$ of milk. The quality and quantity of DNA extracted were measured by spectrophotometric absorption of UV light at 260 and $280 \mathrm{~nm}$. The DNA extracted from milk samples was suitable as a substrate for PCR-RFLP in $75 \%$ of tested samples. A positive correlation $(P<0.001)$ was found between DNA yield and SCC in milk.

For PCR amplification, each reaction mixture (50 $\mu \mathrm{L}$ ) contained $200 \mathrm{ng}$ of DNA template, $3 \mathrm{mM} \mathrm{MgCl} \mathrm{m}_{2}$, $0.4 \mu M$ each primer (forward: 5' TTCTAAAAGTCTC AGGGGCAG $3^{\prime}$; reverse: 5' GGGTTGATAGCCTTGT ATGT 3', according to Ramunno et al., 2000), $400 \mu M$ of each dNTP, 2.5 U of Taq DNA polymerase (Invitrogen Corp., Carlsbad, CA), $50 \mathrm{~m} M \mathrm{KCl}$, and $20 \mathrm{~m} M$ Tris$\mathrm{HCl}, \mathrm{pH}$ 8.4. The PCR reactions were carried out in a thermocycler (i-Cycler, Bio-Rad, Hercules, CA) under the following conditions: a denaturation step at $94^{\circ} \mathrm{C}$ for $3 \mathrm{~min}$ followed by 30 cycles of $94^{\circ} \mathrm{C}$ for $45 \mathrm{~s}, 55^{\circ} \mathrm{C}$ for
$45 \mathrm{~s}$, and $72^{\circ} \mathrm{C}$ for $2 \mathrm{~min}$. A final extension step at $72^{\circ} \mathrm{C}$ for 10 min was performed. Aliquots of $10 \mu \mathrm{L}$ of each PCR product were digested with $10 \mathrm{U}$ of $\mathrm{XmnI}$ endonuclease for $3 \mathrm{~h}$ at $37^{\circ} \mathrm{C}$ following the supplier's instructions for buffer conditions. The PCR and digestion products were electrophoresed in a $4 \%$ agarose gel, stained with ethidium bromide. The resulting DNA fragments were visualized by UV transillumination (Gel Doc EQ system, Bio-Rad, Watford, UK).

The identification of haplotypes determined by the 2 polymorphic sites located in exon 9 and in intron 9 was possible by analyzing the RFLP determined by $X m n I$ digestion.

The PCR digested products obtained from blood and milk samples are reported in Figure 1. The haplotypes identified are associated with different CSN1S1 alleles according to Ramunno et al. (2000). The figure clearly shows comparable digested fragments of PCR products from blood and milk DNA.

In conclusion, a toxic solvent-free and inexpensive method for milk somatic cell DNA extraction was implemented. The present technique shows that milk is a suitable source of DNA for PCR amplification and enzymatic digestion. Compared with blood, the use of milk as source of DNA is less expensive and less stressful for animals, because it does not require capture, handling, and venipuncture.

\section{REFERENCES}

Amills, M., O. Francino, M. Jansa, and A. Sànchez. 1997. Isolation of genomic DNA from milk samples by using Chelex resin. J. Dairy Res. 64:231-238. 
Cremonesi, P., B. Castiglioni, G. Malferrari, I. Biunno, C. Vimercati, P. Moroni, S. Moranti, and M. Luzzana. 2006. Improved method for rapid DNA extarction of mastitis pathogens directly from milk. J. Dairy Sci. 89:163-169.

d'Angelo, F., E. Ciani, A. Sevi, M. Albenzio, R. Ciampolini, and D. Cianci. 2006. The genetic variability of the Podolica cattle breed from the Gargano area. Preliminary results. Ital. J. Anim. Sci. $5: 79-85$.

Feligini, M., S. Frati, V. C. Curik, A. Brambilla, P. Parma, I. Curik, G. F. Greppi, and G. Enne. 2005. Caprine $\alpha_{\mathrm{s} 1}$-casein polymorphism: Characterization of $\mathrm{A}, \mathrm{B}, \mathrm{E}$ and $\mathrm{F}$ variants by means of various biochemical and molecular techniques. Food Technol. Biotechnol. 43:123-132.
International Dairy Federation (FIL-IDF). 1995. Enumeration of somatic cells; Standard no. 148A. FIL-IDF, Brussels, Belgium.

Lipkin, E., A. Shalom, H. Khatib, M. Soller, and A. Friedmann. 1993. Milk as a source of deoxyribonucleic acid and as a substrate for the polymerase chain reaction. J. Dairy Sci. 76:2025-2032.

Paape, M. J., G. R. Wiggans, D. D. Bannerman, D. L. Thomas, A. H. Sanders, A. Contreras, P. Moroni, and R. H. Miller. 2007. Monitoring goat and sheep milk somatic cell counts. Small Rumin. Res. 68:114-125.

Ramunno, L., G. Cosenza, M. Pappalardo, N. Pastore, D. Gallo, P. Di Gregorio, and P. Masina. 2000. Identification of the goat CSN1S1 ${ }^{\mathrm{F}}$ allele by means of PCR-RFLP method. Anim. Genet. 31:342. 